\title{
Comparison of extenders and storage temperature in chilling canine semen
}

\section{Diferentes diluentes e temperaturas de armazenamento para a refrigeração de sêmen canino}

\author{
Tatiana Almeida Pignataro ${ }^{1}$ (D) , Jessica Maresch de Araújo ${ }^{1}$ (D) , Aline Batista Silva ${ }^{1}$ (D) , \\ Mariane Leão Freitas ${ }^{1}$ (D) , Heitor Castro Alves Teixeira1 ${ }^{1}$, , Ivo Pivato ${ }^{1}$ (D) , Rodrigo \\ Arruda Oliveira ${ }^{\text {* }}$ (D) \\ ${ }^{1}$ Laboratório de Reprodução Animal - FAV - Universidade de Brasília, Brasília, DF, Brazil. \\ *Correspondent - rodrigoarruda@unb.br
}

\begin{abstract}
This study aimed to compare the effects a commercial milk-based extender and a self-made egg yolk extender had on the quality of canine semen stored at two different temperatures, $5^{\circ} \mathrm{C}$ or $15^{\circ} \mathrm{C}$. The ejaculate obtained was split into two aliquots of equal volume and diluted with the milk or egg yolk extender. The final concentration was $100 \times 10^{6}$ spermatozoa/mL. Diluted semen was placed in transport

containers and maintained at final storage temperatures of $5^{\circ} \mathrm{C}$ and $15^{\circ} \mathrm{C}$. The quality of the chilled semen was assessed 12,24 , and 36 hours after storage. Semen diluted with the milk extender had higher motility, vigour, and plasma membrane integrity $(p<0.05)$ of the spermatozoa than that diluted with the egg yolk extender. No difference in the semen quality was observed between the stored temperatures in both the groups. The difference observed between the extenders could be due to the standard formulation of the commercial milk extender and the presence of glucose in the mixture. In conclusion, the milk extender was better than the egg yolk extender at preserving the motility, viability, and membrane integrity of chilled canine semen for up to 36 hours. The storage temperature did not seem to affect the semen quality, suggesting that canine semen can be refrigerated at $15^{\circ} \mathrm{C}$.
\end{abstract}

Seção: Medicina Veterinária Received April 16, 2018

Accepted

September, 4, 2019

Published

March 13, 2020

www.revistas.ufg.br/vet

visit the website to get the how to cite in the article page.
Keywords: canine semen, extender, semen storage, temperature storage, cooled semen

\section{Resumo}

O objetivo desse estudo foi avaliar a influência de um diluente comercial à base de leite, comparado à um diluente preparado com de gema de ovo na qualidade do sêmen de cão, armazenado em duas diferentes temperaturas $\left(5^{\circ} \mathrm{C}\right.$ ou $15^{\circ} \mathrm{C}$ ). O ejaculado obtido foi dividido em duas alíquotas de volumes iguais, que foram diluídas com o diluente leite ou o diluente gema de ovo, apresentando uma concentração final de $100 \times 10^{6}$ espermatozoides $/ \mathrm{mL}$. O sêmen diluído foi colocado em caixas de transporte, mantendo temperaturas finais de refrigeração de $5^{\circ} \mathrm{C}$ e $15^{\circ} \mathrm{C}$. A qualidade do sêmen refrigerado foi avaliada após 12, 24 e 36h de armazenamento. O sêmen diluído com o diluente leite resultou em maior motilidade, vigor e integridade de membrana plasmática 
$(p<0,05)$ dos espermatozoides que o diluído com o diluente gema de ovo. Dentro de cada grupo, não foi encontrada nenhuma influencia da temperatura de armazenamento em relação à qualidade do sêmen. A diferença observada entre os diluentes, pode ter ocorrido devido à formulação padrão do diluente comercial à base de leite, além da presença de glicose em sua composição. Em conclusão, o diluente leite apresentou superior preservação da motilidade, viabilidade e integridade de membrana plasmática do sêmen de cão refrigerado, por até $36 \mathrm{~h}$ de armazenamento, que o diluente gema de ovo, e a temperatura de armazenamento não interferiu na qualidade seminal, sugerindo que $15^{\circ} \mathrm{C}$ também pode ser utilizado para a refrigeração do sêmen canino.

Palavras-chave: diluente, armazenamento de sêmen, temperatura de armazenamento seminal, sêmen refrigerado.

\section{Introduction}

A significant feature of spermatozoa cell biology is capacitation. Full capacitation is required for fertilisation as capacitation induces hyperactivated motility, spermzona pellucida recognition, and acrosome exocytosis. Spermatozoa capacitation is characterised by an efflux of cholesterol from the plasma membrane and a global increase in tyrosine phosphorylation. Low levels of reactive oxygen species (ROS) results in a reduction-capacitation (redox)-regulated event ${ }^{(1)}$. However, spermatozoa are highly sensitive to oxidative damage and cooling of the semen induces plasma membrane damage because the membrane is susceptible to lipid peroxidation when exposed to $\operatorname{ROS}^{(1,2,3)}$. Sperm is particularly susceptible to oxidative stress and peroxidative attack by ROS. It is, particularly, vulnerable to superoxide anion and hydrogen peroxide due to its limited ability to store antioxidant enzymes and its unsaturated fatty acid-rich membrane ${ }^{(3,4)}$. ROS is responsible for physiologically driving signal transduction processes associated with sperm capacitation. ROS also leads to a state of oxidative stress that impairs the potential for fertilisation and the capability of gametes to initiate normal embryonic development depending on their concentration ${ }^{(1)}$.

To protect sperm cells from oxidative damage caused by higher concentrations of ROS and preserve the integrity and fertility potential of the spermatozoa, research concerning semen extenders is highly important. Chilling and cryopreservation protocols have a number of steps to reduce the temperature of the sperm, dehydrate the sperm, and induce intra- and extra-cellular freezing ${ }^{(3,5)}$. Dog spermatozoa are more resistant to cold shock than to bull, boar, and ram spermatozoa due to a low ratio of phospholipid-bound polyunsaturated/saturated fatty acids. However, compared to other domestic species semen, canine frozen-thawed semen possesses low viability and motility post-thaw and has higher susceptibility to decreased temperature, osmotic stress, cryoprotectant toxicity, and intra- and extra-cellular ice formation ${ }^{(1,5)}$. The lack of sperm fertility parameters for male dogs complicates data assessment 
as most parameters are extrapolations of research and clinical observations from other species ${ }^{(4)}$. However, if correctly performed, artificial insemination with chilled semen can provide a pregnancy rate similar to that of fresh semen (95\% and 94\% respectively) ${ }^{(4)}$.

Artificial insemination has become more prevalent in recentyears due to improvements in the techniques for canine semen preservation at low temperatures ${ }^{(6)}$. Compared to frozen semen, chilled semen is easier to process and transport and does not need special techniques and expensive equipment ${ }^{(6,7)}$. However, the longevity of chilled sperm is limited and requires the use of extenders to maintain semen quality ${ }^{(8)}$. Factors such as storage temperature and refrigeration speed can also help preserve chilled canine semen ${ }^{(9)}$.

The standard semen extenders used for cooled dog semen are usually made with egg yolk. However, this has disadvantages over a commercial diluent, as egg yolk functions as a microbial culture medium, and generally does not undergo any sterilisation treatment, such as pasteurisation. It is not possible to quantify and standardise the components present in egg yolk, because its composition depends on the diet and management of the chicken. Additionally, egg yolk can interfere with semen quality assumptions, generating artefacts that obscure the visualisation of sperm, especially when using automated analyses ${ }^{(9)}$.

Skimmed milk is also used as an extender for liquid or frozen semen from bulls and stallions ${ }^{(3)}$. The efficacy of skimmed milk is considered as good as an egg yolk based extender in preserving sperm ${ }^{(10)}$. Both egg yolk and skimmed milk have the same function, which is to preserve the stability of the spermatozoa's membranes. This helps to protect the sperm from irreversible structural and functional damage brought on by cold shock during refrigeration ${ }^{(11)}$.

Our study aimed to compare the effects a commercial equine extender and a selfmade egg yolk extender had on the quality of cooled canine semen stored at two different temperatures, $5^{\circ} \mathrm{C}$ and $15^{\circ} \mathrm{C}$, for 36 hours.

\section{Material and methods}

All experimental procedures were approved by the Ethics Committee in Animal Experimentation of the Institute of Biological Sciences at University of Brasília, under Protocol UnBDOC No 158,647/2014.

Eighteen ejaculates were collected by manual masturbation from six male German Shepherds. Three ejaculates were taken from each dog once a week. The dogs had an average weight of $38 \pm 3.6 \mathrm{~kg}$ and were between 2 and 6 years old. The samples were collected in the presence of a female on heat. The six dogs were pedigree purebred and were bred in kennels located in Brasília Federal District (central Brazil: $15^{\circ} 44^{\prime} 05.6^{\prime \prime} \mathrm{S}, 47^{\circ} 44^{\prime} 20.5^{\prime \prime} \mathrm{W}$ ).

Breeding soundness examination was performed. This was done through a general 
clinical examination; palpation; visual inspection of the external reproductive system; height, length, and width measurements of both the testicles with a pachymeter; and semen analysis. Examinations were done according to the parameters stipulated by the Brazilian College of Animal Breeding(12).

Immediately after the semen was collected $(0 \mathrm{~h})$, volume $(\mathrm{mL})$, aspect (density and colour), $\mathrm{pH}$ (evaluated through $\mathrm{pH}$ measuring tapes), sperm concentration, total motility, vigour, sperm morphology, and plasma membrane integrity were assessed. To assess its total motility and vigour, $20 \mu \mathrm{L}$ of semen was placed on a pre-heated (37 $\left.{ }^{\circ} \mathrm{C}\right)$ slide covered with a coverslip and viewed under a 200X optical microscope.

To determine the concentration and sperm morphology, semen was diluted (1:20) in buffered formalin citrate. To assess the sperm concentration, a haematology chamber (Neubauer) with a 200X optical microscope was used. Sperm morphology was evaluated using phase-contrast microscopy with the humid chamber technique. In this technique, $20 \mu \mathrm{L}$ of the sample was placed between the slide and the coverslip and 200 cells were evaluated at $1000 \mathrm{X}$ magnification ${ }^{(12)}$.

For the evaluation of the plasma membrane integrity or viability, a supravital eosinnigrosin staining technique (LIVE/DEAD) was used. Equal volumes $(20 \mu \mathrm{L})$ of the semen and stain were mixed and transferred to a preheated $\left(37^{\circ} \mathrm{C}\right)$ labelled microscope slide. They were then smeared by sliding a coverslip in front of it. The smears were air-dried and examined directly. Samples were evaluated using microscopy at 1000X magnification ${ }^{(13)}$. Two hundred sperm cells were counted per sample, and stained cells were classified as those that were damaged.(14).

The ejaculate obtained was split into two aliquots of equal volume. They were split into the two groups that contained a milk extender, a commercial equine extender of skimmed milk powder, glucose, sodium bicarbonate, and amikacin (BotuSêmen, Botupharma, Botucatu, SP) and an egg yolk extender, a self-made extender containing $12 \mathrm{~mL}$ of egg yolk, $48 \mathrm{~mL}$ of UHT skimmed milk, $6 \mu \mathrm{g}$ of streptomycin, and $386 \mu \mathrm{g}$ of penicillin. This was method was adapted from the study by Romagnoli(15). Semen was placed in $0.5-\mu \mathrm{L}$ microcentrifuge tubes, with a final concentration of $100 \times 10^{6}$ spermatozoa/mL.

Tubes were placed in BotuFlex transport containers (Botupharma, Botucatu, SP). Final storage temperatures of $5^{\circ} \mathrm{C}$ and $15^{\circ} \mathrm{C}$ were maintained, following the manufacturer's protocol. One transport box for each temperature was used per cooling period (12, 24 , and 36 hours).

Cooled semen was evaluated after 12, 24, and 36 hours of storage. Microcentrifuge tubes were placed in a $37{ }^{\circ} \mathrm{C}$ water bath for five minutes. Following this, an analysis of their total motility, vigour, and plasma membrane integrity was performed, as described for fresh semen.

Data were analysed to assess its normality and homoscedasticity using CochranBartlet tests. As normality was not seen, data were transformed to a log 10 scale. An analysis of the motility, vigour, and membrane integrity results were performed using ANOVA and Tukey test $(p<0.05)$. These analyses were conducted using the R software 
programme.

\section{Results}

Fresh semen had a volume of $11.5 \pm 5.9 \mathrm{~mL}$, concentration of $175 . \pm 103.1 \times 10^{6} \mathrm{sperm} /$ $\mathrm{mL}$, pH of 6.6. \pm 0.2 , motility of $86.4 \pm 9.8 \%$, vigour of $4.0 \pm 0.5$, and membrane integrity of $70.4 \pm 27.9 \%$. For sperm morphology, $68.1 \pm 21.6 \%$ of the spermatozoa were considered normal, $10.0 \pm 6.3 \%$ had minor defects, and $21.7 \pm 18.2 \%$ had major defects. The semen of all ejaculates was an opalescent white colour with a density ranging from aqueous to milky. This conforms to the standardised CBRA ${ }^{(12)}$ parameters for dogs.

The motility, vigour, and plasma membrane integrity data of the cooled semen are described in Table 1. Semen diluted with the milk extender and stored at $5{ }^{\circ} \mathrm{C}$ or $15^{\circ} \mathrm{C}$ resulted in higher motility and vigour $(p<0.05)$ than that diluted with the egg yolk extender for all periods. The membrane integrity was superior for the milk extender than the egg yolk extender $(p<0.05)$ at $15^{\circ} \mathrm{C}$ for all periods and at $5^{\circ} \mathrm{C}$ for 12 hours. The quality of the cooled semen decreased during storage $(p<0.05)$ between each period $(12,24$, and 36 hours) with both the extenders.

Table 1. Evaluation of the total motility (MT, \%), vigour, and membrane integrity (MI, \%) of cooled canine semen at different periods $(12,24$, and 36 hours), following its dilution with two extenders (milk and egg yolk extender). Two different temperatures $\left(5^{\circ} \mathrm{C}\right.$ and $\left.15^{\circ} \mathrm{C}\right)$ were maintained. Mean \pm standard deviation

\begin{tabular}{|c|c|c|c|c|c|}
\hline & & \multicolumn{2}{|c|}{ MILK EXTENDER } & \multicolumn{2}{|c|}{ EGG YOLK EXTENDER } \\
\hline & & $5^{\circ} \mathrm{C}$ & $15^{\circ} \mathrm{C}$ & $5^{\circ} \mathrm{C}$ & $15^{\circ} \mathrm{C}$ \\
\hline \multirow{3}{*}{$\begin{array}{c}12 \\
H^{*}\end{array}$} & MT & $76.9 \pm 17.9^{a}$ & $79.4 \pm 17.8^{a}$ & $70.8 \pm 15.8^{b}$ & $72.8 \pm 20.3^{b}$ \\
\hline & Vigour & $3.8 \pm 0.5^{a}$ & $3.8 \pm 0.5^{a}$ & $3.6 \pm 0.7^{b}$ & $3.6 \pm 0.6^{b}$ \\
\hline & $\mathrm{MI}$ & $78.3 \pm 14.8^{a}$ & $78.7 \pm 15.9^{a}$ & $71.2 \pm 9.0^{b}$ & $76.7 \pm 13.3^{b}$ \\
\hline \multirow{3}{*}{$\begin{array}{l}24 \\
\mathrm{H}^{*}\end{array}$} & $\mathrm{MT}$ & $61.9 \pm 22.4^{a}$ & $69.4 \pm 17.2^{a}$ & $51.4 \pm 23.6^{b}$ & $56.1 \pm 25.0^{b}$ \\
\hline & Vigour & $3.5 \pm 0.7^{a}$ & $3.7 \pm 0.7^{a}$ & $3.2 \pm 0.8^{b}$ & $3.3 \pm 0.8^{b}$ \\
\hline & $\mathrm{MI}$ & $68.3 \pm 18.9^{a b}$ & $76.0 \pm 13.3^{a}$ & $64.5 \pm 15.6^{b}$ & $70.1 \pm 20.5^{a b}$ \\
\hline \multirow{3}{*}{$\begin{array}{l}36 \\
H^{*}\end{array}$} & $\mathrm{MT}$ & $50.8 \pm 22.0^{a}$ & $58.1 \pm 18.8^{a}$ & $41.1 \pm 24.7^{b}$ & $43.3 \pm 23.5^{b}$ \\
\hline & Vigour & $2.9 \pm 0.9^{a}$ & $3.2 \pm 0.5^{a}$ & $2.7 \pm 0.7^{b}$ & $2.7 \pm 0.5^{b}$ \\
\hline & $\mathrm{MI}$ & $62.5 \pm 20.2^{b}$ & $70.6 \pm 14.6^{a}$ & $61.4 \pm 21.6^{b}$ & $63.2 \pm 19.4^{b}$ \\
\hline
\end{tabular}




\section{Discussion}

The commercial equine milk extender was superior to the egg yolk extender for the evaluated parameters of canine sperm quality.

Using egg yolk in an extender has disadvantages as its components are not quantifiable and variations between each egg yolk can exist. Additionally, there is a greater risk of contamination before the semen is diluted depending on the origin of the eggs, manipulation of the extender, and the influence of antibiotics.

Canine spermatozoa require exogenous substrates to preserve intracellular energy reserves and support motility. The consumption of glycolysable sugars can provide energy through mitochondrial oxidative phosphorylation and glycolysis ${ }^{(17)}$. Ponglowhapan et al. ${ }^{(17)}$ showed that $20 \%$ of egg yolk in a distilled water mixture contains 3-4 mM of glucose, but the addition of a higher concentration (70 mM) of glucose in an egg yolk extender better preserved the sperm motility and movement patterns than a control extender containing only egg yolk. Therefore, the presence of glucose may also explain the higher motility maintained in the semen diluted with the milk extender that was observed in this study.

We also evaluated storage temperatures for canine semen. While chilling semen reduces the metabolic activity of the spermatozoa and, therefore, preserves the sperm quality parameters, such as motility and viability ${ }^{(17)}$, it can also expose spermatozoa to cold shock, resulting in irreversible damage ${ }^{(11)}$. Despite the frequent use of $4{ }^{\circ} \mathrm{C}-5$ ${ }^{\circ} \mathrm{C}$ temperature for cooling canine semen $(8,11,18,19)$, no influence of temperature on the semen quality was observed in this study, suggesting that a temperature of $15^{\circ} \mathrm{C}$ can also be used for short-term storage.

This result differs from that reported by Hori et al. ${ }^{(20)}$, who concluded that canine semen qualities could be maintained for up to 48 hours when semen samples were stored at a temperature of $4{ }^{\circ} \mathrm{C}-12^{\circ} \mathrm{C}$. Hori et al. ${ }^{(20)}$ also found that storing the semen samples at $\geq 16^{\circ} \mathrm{C}$ resulted in decreased sperm motility and increased sperm abnormalities. As there are few studies that evaluate the ideal temperature range for storing chilled canine semen, we believe that further studies, which take into account storage temperature, cooling rate, and the transport container, are needed.

\section{Conclusions}

In conclusion, the milk extender was superior to the self-made egg yolk extender in preserving cooled canine semen up to 36 hours of storage. No differences concerning the motility, viability, and integrity of the membrane were observed after short-term storage of semen at $5^{\circ} \mathrm{Cor} 15^{\circ} \mathrm{C}$. However, further investigation is needed to understand the interactions that the extender, temperature, cooling rate, and transport container have on sperm quality and fertility in canines. 


\section{References}

1. Aitken, R. J. Reactive oxygen species as mediators of sperm capacitation and pathological damage. Mol Reprod Dev, 2017, 1039-1052.

2. Andersen A H, Thinnesen M, Failing K, Goericke-Pesch S. Effect of reduced glutathione (GSH) supplementation to Tris-egg yolk extender on chilled semen variables of dogs. Anim Reprod Sci, 2018, 145-153.

3. Oliveira RA, Wolf CA, Viu MAO, Gambarini ML. Cooling of equine semen at $16{ }^{\circ} \mathrm{C}$ for $36 \mathrm{~h}$ with the addition of cysteine in different concentration. Pferdeheilkund, 2015, 27-32.

4. Hesser A, Darr C, Gonzales K, Power H, Scanlan T, Thompson J, Love C, Christensen B, Meyers S. Semen Evaluation and Fertility Assessment in a Purebred Dog Breeding Facility. Theriogenology, 2017, 115-123.

5. Lucio C F, Regazzi F M, Silva L C G, Angrimani D S R, Nichi M, Vannucchi C I. Oxidative stress at different stages of two-step semen cryopreservation procedures in dogs.Theriogenology, 2016, 1568-1575.

6. Hori T, Masuda T, Kobayashi M, Kawakami E. Role of prostatic fluid in cooled canine epipidymal sperm. Reprod Dom Anim, 2017, 00:1-6.

7. Linde-Forsberg C. Achieving canine pregnancy by using frozen of chilled extended semen. Vet Clin North Am Small Anim Pract, 1991, 21:467-485.

8. Rodenas C, Parrilla I, Roca J, Martinez EA, Lucas X. Quality of chilled and cold-stored $\left(5^{\circ} \mathrm{C}\right)$ canine spermatozoa submitted to different rapid cooling rates. Theriogenology, 2014, 82:621-626.

9. Bencharif D, Amirat-Briand L, Le Guillou J, Anton M, Schmitt E, Desherces S, Delhomme G, Langlos M-L, Destrumelle $S$, Vera-Munoz $O$, Barrière $P$, Tainturier $D$. Canine-chilled sperm: study of a semen extender made with low-density lipoproteins from hen egg yolk supplemented with glutamine. Reprod Dom Anim, 2013, 48:258-266.]

10. Manjunath P. New insights 214 into the understanding of the mechanism of sperm protection by extender components. Anim Reprod, 2012, 9(4):809-815.

11. Belala R, Delay J, Amirat L, Ropers M-H, Le Guillou J, Anton M, Schmitt E, Thorin C, Michaud S, Kaidi $R$, Tainturier $D$, Bencharif $D$. The benefits of liposomes for chilling canine sperm for 4 days at $4{ }^{\circ} \mathrm{C}$. Anim Reprod Sci, 2016, 168:100-109.

12. CBRA. Colégio Brasileiro de Reprodução Animal. Manual para exame andrológico e avaliação de sêmen animal. 3rd ed. Belo Horizonte; 2013.

13. Oliveira RA, Wolf CA, Viu MAO, Gambarini ML. Addition of glutathione to an extender for frozen equine semen. J Equine Vet Sci, 2013, 33:1148-1152.

14. Dott HM, Foster GC. A techinique for studying the morphology of mammalian spermatozoa which are eosinophilic in a differential live/dead stain. J Reprod Fert, 1972, 29:443-445.

15. Romagnoli S. Canine artificial insemination with fresh, refrigerated and frozen semen. In Proceedings of the Veterinary Sciences Congress, Oieras, Portugal. Portugal: SPCV. 2002, pp.167-170.

16. Ponglowhapan S, Essén-Gustavsson B, Forsberg CL. Influence of glucose and fructose in the extender during long-term storage of chilled canine semen. Theriogenology, 2004, 62:1498-1517.

17. Meyers SA. Dry storage of sperm: applications in primates and domestic animals. Reprod Fertil Dev, 2006, 18:1-5. 
18. Verstegen JP, Onclin K, Iguer-Ouada M. Long-term motility and fertility conservation of chilled canine semen using egg yolk added Tris-glucose extender: in vitro and in vivo studies. Theriogenology, 2005, 64:720-733.

19. Kasimanickam VR, Kasimanickam RK, Memon MA, Rogers HA. Effect of extenders on sperm mitochondrial membrane, plasma membrane and sperm kinetics during liquid storage of canine semen at $5{ }^{\circ} \mathrm{C}$. Anim Reprod Sci, 2012, 136:139-145.

20. Hori T, Yoshikuni R, Kobayashi M, Kawakami E. Effects of storage temperature and semen extender on stored canine semen. J Vet Med Sci, 2014, 76(2):259-263. 